\title{
GAMBARAN KADAR ALBUMINURIA PADA SUBJEK DIABETES MELITUS DENGAN DAN TANPA PENYAKIT JANTUNG KORONER
}

\author{
${ }^{1}$ Sandy Cendra \\ ${ }^{2}$ Emma Moeis \\ ${ }^{2}$ Yuanita Langi \\ ${ }^{1}$ Kandidat Skripsi Fakultas Kedokteran Universitas Sam Ratulangi Manado \\ ${ }^{2}$ Bagian Interna Fakultas Kedokteran Universitas Sam Ratulangi Manado \\ Email : sandy_cendra@ymail.com
}

\begin{abstract}
Albuminuria is a marker of the decline in renal physiology and function of endothelial. Endothelial dysfunction is an early pathogenesis of coronary heart disease (CHD). High coronary heart disease complications in patients with diabetes mellitus (DM). Objective To know the description and differences in levels of albuminuria in diabetic patients with and without CHD inpoli Metabolic and Endocrine and poli Heart BLU. RSU. Prof. dr. R. D Kandou Manado. Research Method: Cross Sectional descriptive analytic study conducted in patients with diabetes mellitus pieces with and without coronary heart disease in Poli Endocrine Metabolic and poli heart BLU. RSU. Prof. dr. R. D Kandou Manado period November 2012 - November 2013. Results: From 34 patients with diabetes mellitus found the number of diabetic patients with CHD were 17 patients and 17 patients for diabetes without CHD, which consisted of 14 male patients and 20 female patients. The distribution of the sample based on CHD and sex, showed that diabetic patients with CHD were 9 men (26.47\%) and 8 women (23.53\%). As for diabetic patients without CHD as many as 5 male patients (14.70\%) and 12 female patients (35.30\%). Distribution of the study sample by CHD and RAKU categories showed diabetic patients with CHD were 7 patients (20.59\%) and normal RAKU 10 patients (29.41\%) RAKU abnormal. As for diabetic patients without CHD by 16 patients (47.06\%) and 1 patient RAKU normal (2.94\%) RAKU abnormal.

Conclusion: Albuminuria occurs more frequently in patients with diabetes mellitus with coronary heart disease than diabetes mellitus without coronary heart disease
\end{abstract}

Keywords: Albuminuria, diabetes mellitus, coronary heart disease.

Abstrak: Albuminuria merupakan petanda terjadinya penurunan faal ginjal dan disfungsi endotel. Disfungsi endotel merupakan patogenesis awal penyakit jantung koroner (PJK). Komplikasi penyakit jantung koroner tinggi pada pasien diabetes melitus (DM). Tujuan: Untuk mengetahui gambaran dan perbedaan kadar albuminuria pada pasien DM dengan dan tanpa PJK di Poli Endokrin Metabolik dan Poli Jantung BLU. RSU. Prof. dr. R. D Kandou Manado. Metode Penelitian: Dilakukan penelitian deskriptif analitik lintang potong pada penderita diabetes melitus dengan dan tanpa penyakit jantung koroner di Poli Endokrin Metabolik dan Poli Jantung BLU.RSU. Prof. dr. R. D Kandou Manado periode November 2012 - November 2013. Hasil: Dari 34 pasien Diabetes Melitus ditemukan jumlah pasien DM dengan PJK sebanyak 17 pasien dan 17 pasien untuk DM tanpa PJK, yang terdiri atas 14 orang pasien laki-laki dan 20 pasien wanita. Distribusi sampel berdasarkan PJK dan jenis kelamin, didapatkan hasil pasien DM dengan PJK yaitu sebanyak 9 orang laki-laki (26,47 \%) dan 8 orang perempuan (23,53\%). Sedangkan untuk pasien DM tanpa PJK yaitu sebanyak 5 orang pasien laki-laki (14,70\%) dan 12 orang pasien perempuan (35,30\%). Distribusi sampel penelitian berdasarkan PJK dan RAKU Kategori didapatkan hasil pasien DM dengan PJK sebanyak 7 pasien (20,59\%) RAKU normal dan 10 pasien (29,41\%) RAKU abnormal. Sedangkan untuk pasien DM tanpa PJK sebanyak 16 pasien (47,06\%) RAKU normal dan 1 pasien (2,94\%) RAKU abnormal. Simpulan: Albuminuria lebih banyak terjadi pada pasien diabetes melitus dengan penyakit jantung koroner dibandingkan diabetes melitus tanpa penyakit jantung koroner Kata kunci: Albuminuria, diabetes melitus, penyakit jantung koroner.

Albuminuria merupakan marker (petanda) proteinuria klinis yang merupakan faktor resiko penurunan faal ginjal. ${ }^{1}$ Albumin dalam urin juga merupakan petanda terjadinya disfungsi endotel. Komplikasi penyakit kardiovaskuler tinggi pada pasien diabetes melitus (DM). Komplikasi dapat berupa penyakit jantung koroner (PJK) dan 
disfungsi miokardium. ${ }^{2}$ Patogenesis penyakit jantung koroner diawali dengan terjadinya disfungsi endotel.

Diabetes melitus atau lebih populer dikenal dikalangan masyarakat dengan nama penyakit kencing manis, merupakan satu dari sekian penyakit berbahaya yang ada didunia. Menurut American Diabetes Association (ADA), DM merupakan suatu kelompok penyakit metabolik dengan karakteristik hiperglikemia yang terjadi karena kelainan sekresi insulin, kerja insulin atau kedua-duanya. ${ }^{3}$ Insulin merupakan hormon yang berperan pada metabolisme karbohidrat, lemak dan protein. Insulin meningkatkan transport glukosa dari darah kedalam sel target di jaringan perifer (otot, otak, jaringan lemak, hati dan lain-lain) melalui transporter glukosa 4 (GLUT-4). ${ }^{4}$

World Health Organization (WHO) memprediksi kenaikan jumlah penyandang DM di Indonesia dari 8,4 juta pada tahun 2000 menjadi sekitar 21,3 juta pada tahun 2030. Menurut International Diabetic Federation (IDF) pada tahun 2009 memperkirakan kenaikan jumlah penyandang diabetes melitus dari 7,0 juta tahun 2009 menjadi 12 juta pada tahun 2030. Menurut data Riset Kesehatan Dasar (RISKESDAS) 2007, Sulut memiliki penyandang DM sebesar 8,1 \%. ${ }^{6}$

Komplikasi penyakit kardiovaskuler tinggi pada pasien DM. Di Indonesia, menurut International Classification of Disease 10 (ICD-10) penyakit sistem sirkulasi darah (SSD) yaitu penyakit jantung dan pembuluh darah telah menduduki peringkat pertama sebagai penyebab utama kematian umum pada tahun 2000 berdasarkan hasil Survei Kesehatan Rumah Tangga (SKRT) 2001 sebesar 26,3\%. Proporsi kematian semakin meningkat dengan bertambahnya umur dan meningkat nyata pada usia 35 tahun ke atas. Penyakit sistem sirkulasi darah sebagai penyebab kematian lebih tinggi di perkotaan daripada dipedesaan (31\% vs 23,7\%) namun hampir tidak berbeda menurut jenis kelamin. ${ }^{7}$

Albuminuria adalah adanya albumin dalam urin yang menunjukkan kemungkinan telah terjadinya proses aterosklerosis pada pasien DM. Deteksi dini disfungsi endotel dilakukan melalui pemeriksaan mikroalbuminuria. $^{8}$

Berdasarkan uraian diatas, penelitian dilakukan untuk mengetahui gambaran albuminuria pada penderita DM dengan kejadian penyakit jantung koroner dan DM tanpa penyakit jantung koroner di BLU. RSU. Prof. dr. R. D Kandou Manado.

\section{METODE PENELITIAN}

Desain yang digunakan dalam penelitian ini yakni deskriptif analitik dengan pendekatan lintang potong (cross sectional). Penelitian ini dilakukan pada periode November 2013 sampai Maret 2014 bertempat di Poli Endokrin Metabolik dan Poli Jantung Ilmu Penyakit Dalam BLU. RSU Prof. Dr. R. D. Kandou Manado. Populasi pada penelitian ini adalah seluruh pasien DM dengan dan tanpa PJK yang ada di Poli Endokrin Metabolik dan Poli Jantung BLU. RSU. Prof. dr. R. D Kandou Manado. Sampel pada penelitian ini adalah pasien DM dengan dan tanpa PJK yang memenuhi kriteria peneliti di Poli Endokrin Metabolik dan Poli Jantung BLU. RSU. Prof. dr. R. D Kandou Manado periode November 2012November 2013 dengan menggunakan teknik random sampling.

Penelitian ini dilakukan dengan menggunakan catatan rekam medik dan pemeriksaan RAKU kepada responden. Kemudian data yang diperoleh akan diolah menggunakan SPSS ver.20 dan ditampilkan dalam bentuk tabel dan narasi.

\section{HASIL DAN PEMBAHASAN}

\section{Karakteristik sampel penelitian}

Penelitian dilakukan dengan menggunakan metode deskriptif analitik lintang potong melalui pemeriksaan laboratorium pasien rawat jalan di poli endokrin metabolik dan poli jantung bagian interna BLU. RSU. Prof. dr. R. D Kandou Manado periode November 2012 - November 2013, didapatkan 17 pasien penderita DM dengan PJK dan 17 pasien DM tanpa PJK. 
Cendra, Moeis, Langi; Gambaran Kadar Albuminuria pada Subjek Diabetes...

Tabel 1. Karakteristik sampel penelitian

\begin{tabular}{cccccccc}
\hline Sampel & & N & Min & Maks & Rerata & $\begin{array}{c}\text { Simpang } \\
\text { Baku }\end{array}$ & Distribusi \\
\hline Umur & & 34 & 40 & 70 & 56.12 & 7.36 & .724 \\
PJK + Nilai RAKU & PJK =17 & & 3 & 1470 & 423.94 & 526.721 & .001 \\
& $\begin{array}{c}\text { Tanpa PJK=17 } \\
\text { Laki-laki=14 }\end{array}$ & 34 & 3 & 58 & 9.82 & 14.108 & .000 \\
Jenis Kelamin & Perempuan=20 & 34 & & & & & \\
Nilai RAKU & & 34 & 3 & 1470 & 216.88 & 422.827 & .000 \\
\hline
\end{tabular}

Tabel 2. Distribusi sampel berdasarkan PJK dan jenis kelamin

\begin{tabular}{lcccc}
\hline \multirow{2}{*}{ Sampel } & \multicolumn{2}{c}{ Jenis Kelamin } & \multirow{2}{*}{ Total n (\%) } \\
\cline { 3 - 3 } DM & LJK & $9(26,47 \%)$ & $8(23,53 \%)$ & $17(50 \%)$ \\
& $\begin{array}{c}\text { Tanpa } \\
\text { PJK }\end{array}$ & $5(14,70 \%)$ & $12(35,30 \%)$ & $17(50 \%)$ \\
\hline \multicolumn{2}{r}{ Total n (\%) } & $14(41,18 \%)$ & $20(58,82 \%)$ & $34(100 \%)$ \\
\hline
\end{tabular}

Tabel 3. Distribusi sampel berdasarkan PJK dan RAKU kategori

\begin{tabular}{lcccc}
\hline \multirow{2}{*}{ Sampel } & \multicolumn{3}{c}{ Raku } & \multirow{2}{*}{ Total n (\%) } \\
\cline { 3 - 4 } & Normal n (\%) & Abnormal n (\%) & $17(50 \%)$ \\
\hline \multirow{2}{*}{ DM } & PJK & $7(20,59 \%)$ & $10(29,41 \%)$ & $17(50 \%)$ \\
\hline & $\begin{array}{c}\text { Tanpa } \\
\text { PJK }\end{array}$ & $16(47,06 \%)$ & $1(2,94 \%)$ & $34(100 \%)$ \\
\hline \multicolumn{2}{r}{ Total n (\%) } & $23(67,65 \%)$ & $11(32,35 \%)$ & \\
\hline
\end{tabular}

Tabel 4. Perbedaan kadar albuminuria pada pasien DM dengan dan tanpa PJK

\begin{tabular}{|c|c|c|c|c|}
\hline \multirow{2}{*}{\multicolumn{2}{|c|}{ Sampel }} & \multicolumn{2}{|c|}{ RAKU } & \multirow{2}{*}{$\mathbf{p}$} \\
\hline & & Abnormal & Normal & \\
\hline $\mathrm{DM}$ & $\begin{array}{c}\text { PJK } \\
\text { Tanpa PJK }\end{array}$ & $\begin{array}{c}10 \\
1\end{array}$ & $\begin{array}{c}7 \\
16\end{array}$ & 0,002 \\
\hline
\end{tabular}

\section{Distribusi sampel peneltian}

Distribusi sampel berdasarkan PJK dan jenis kelamin, didapatkan hasil pasien DM dengan PJK yaitu sebanyak 9 orang laki-laki $(26,47 \%)$ dan 8 orang perempuan (23,53\%). Sedangkan untuk pasien DM tanpa PJK yaitu sebanyak 5 orang pasien laki-laki $(14,70 \%)$ dan 12 orang pasien perempuan $(35,30 \%)$.

Distribusi sampel penelitian berdasarkan PJK dan RAKU Kategori didapatkan hasil pasien DM dengan PJK memiliki lebih banyak kadar RAKU abnormal dibanding normal yaitu 7 pasien (20,59\%) dengan RAKU normal dan 10 pasien (29,41\%) 
RAKU abnormal. Sedangkan untuk pasien DM tanpa PJK memiliki lebih banyak kadar RAKU normal dibanding abnormal yaitu 16 pasien (47,06\%) dengan RAKU normal dan 1 pasien (2,94\%) dengan RAKU abnormal.

Dari 34 sampel penelitian yang dibagi menjadi 2 kategori yaitu RAKU normal \& RAKU tinggi.Selanjutnya dihitung odds ratio (OR) dengan membuat tabulasi silang antara RAKU dengan DM dengan dan tanpa PJK. Dari hasil uji ditemukan hubungan bermakna $(p=0,002)$ antara albuminuria dan DM dengan PJK.

\section{SIMPULAN DAN SARAN}

Dari hasil penelitian terhadap pasien DM dengan PJK dan DM tanpa PJK di BLU. RSU. Prof. dr. R. D. Kandou Manado periode November 2012- November 2013 dapat disimpukan bahwa terdapat perbedaan bermakna antara albuminuria pada pasien DM dengan PJK dan Pasien DM tanpa PJK yakni albuminuria lebih banyak terjadi pada pasien DM dengan PJK serta albuminuria lebih banyak terjadi pada pasien laki-laki daripada wanita. Ini berarti albuminuria, penyakit ginjal dan kardiovaskuler (PJK) memiliki hubungan yang erat satu sama lain yang mana albuminuria merupakan salah satu petanda gangguan fungsi ginjal dan kardiovaskuler pada pasien DM. ${ }^{9}$

Pada studi sebelumnya yang di lakukan oleh Thakkar dkk tahun 2011, sebanyak 61 pasien yang terdiri dari 35 laki-laki dan 26 perempuan, termasuk dalam studi ini. Secara keseluruhan prevalensi mikroalbuminuria dalam penelitian ini adalah 54,09\%. Di antara pasien dengan mikroalbuminuria, 24 (68,5\%) adalah lakilaki dan 9 (34.61\%) adalah perempuan. ${ }^{10}$ Sangat diharapkan agar dapat dilakukan penanganan dan pengobatan pada pasien DM dengan PJK sehingga memperlambat progresivitas gangguan ginjal mencapai tahap End Stage Renal Disease dan mengoptimalkan fungsi ginjal yang masih ada. Pasien dengan albuminuria harus dirujuk ke ahli ginjal untuk mendapatkan pengobatan guna mencegah berkembangnya kerusakan ginjal ke tingkat End Stage Renal
Disease (ESRD). ${ }^{11}$ Untuk DM tanpa PJK mencegah terjadinya komplikasi terutama PJK dan kerusakan ginjal.

\section{DAFTAR PUSTAKA}

1. Bawazier LA. Proteinuria. In: Sudoyo AW,Setiyohadi B, Alwi I, Simandibrata MK, Setiati S,editors.Ilmu Penyakit Dalam Jilid II.Edisi ke-5. Jakarta : 2009. Hal.958

2. Radi B. Diabetes Melitus sebagai Faktor Resiko Utama Penyakit Jantung. National Cardiovascular Center Harapan Kita. 2007 (cited 2013 oct 16). Available from: http://www.pjnhk.go.id/content/view/191/3/

3. Suyono S. Kecenderungan Peningkatan Jumlah Penyandang Diabetes. In: Soegondo S, Soewondo P, Subekti I, editors. Penatalaksanaan Dibetes Melitus Terpadu. Edisi ke-2. Jakarta; 2009.hal.7

4. Sulistyoningrum E . Tinjauan molekuler \& aspek klinis resistensi insulin. Jurnal tinjauan resistensi insulin.2010;4:131. Available from: http://kedokteran.unsoed. ac.id/Files/Jurnal/mandala\%20mei\%202010 \%20pdf/TINJAUAN\%20MOLEKULAR\%2 0DAN\%20ASPEK\%20KLINIS\%20RESIST ENSI\%20INSULIN.pdf

5. RI Rangking Keempat Jumlah Penderita Diabetes Terbanyak DiDunia. Pusat Data dan Informasi PERSI. 2011 (cited oct 16). Available from: http://www.pdpersi. co.id/content $/$ news.php?catid $=23 \&$ mid $=5 \&$ n id $=618$

6. RISKESDAS 2007. Badan Penelitian \& Pengembangan Kesehatan. 2008 (cited oct 16). Available from :www.litbang.depkes. go.id/bl_riskesdas2007

7. Delima, Mihardja L, Siswoyo H. Prevalensi dan faktor determinan penyekit jantung di Indonesia. Buku penelitian kesehatan. 2009;37:143. Available from:

http://ejournal.litbang.depkes.go.id/index.ph p/BPK/article/viewFile/2182/1103

8. Friedman A, Marrero D, Ma Y, Ackermann R, Narayan KMV, Connor EB, dkk. Value of Urinary Albumin to Creatinin Ratio as Predictor of Type 2 Diabetes in Pre-Diabetic Individuals. 2009 (cited 2013 oct 16). Available from:

http://www.ncbi.nlm.nih.gov/pmc/articles/P MC2584193/?report=classic

9. Heerspink HJL, Holtkamp FA, Zeeuw D, Ravid M. Monitoring Kidney Function and Albuminuria in Patients With Diabetes. Diabetes care. 2011;325,328. Available 
from:

http://care.diabetesjournals.org/content/34/S

upplement_2/S325.extract

10. Thakkar B, Arora K, Vekariya R, Lulania

M, Agnihotri AS. Prevalence of

Microalbuminuria in Newly Diagnosed

Type 2 Diabetes Mellitus. NJIRM. 2011;

2:22,23. Available from: http://www. scopemed.org/?mno=13008

11. Grundy SM, Benjamin IJ, Burke GL, Chait A, Eckel RH, Howard BV, et al. Diabetes and Cardiovascular Disease: A Statement for Healthcare Professionals From the American Heart Association. Journal of the American Health Association. 1999; 100:1139. Available from: http://circ. ahajournals.org/content/100/10/1134.full 